\title{
Analisis Piutang Tak Tertagih pada PT Astra International Tbk
}

\author{
Aris Munandar ${ }^{1)^{*}}$, Nurul Huda ${ }^{2)}$, Muhajirin ${ }^{3)}$ \\ ${ }^{1,2,3)}$ Program Studi Manajemen, Sekolah Tinggi Ilmu Ekomomi Bima \\ e-mail: arizqars@gmail.com ${ }^{1 *}$
}

\begin{abstract}
Abstrak
Penelitian bertujuan untung menganalisis besarnya piutang tak tertagih pad PT Astra Internasional Tbk dari tahun 2012 sampai 2016. Jenis penelitian yang dilakukan deskriptif dengan menggunakan data primer. Teknik analisis data yang dilakukan pada penelitian ini adalah analisis piutang tak tertagih dan uji t-test one sample. Hasil penelitian ini dapat disimpulkan, bahwa piutang tak tertagih PT Astra Interanasional Tbk rata - rata selama 5 tahun terakhir sebesar 3,36 \% yang berarti masuk dalam kategori besar. Dari hasil pengujian hipotesis diperoleh bahwa piutang tak tertagih pada PT Astra International Tbk lebih dari 3\% dari yang diharapkan. Saran untuk kesempurnaan penelitian selanjutnya adalah diharapkan menambah tahun penelitian dan menggunakan data terbaru dan dapat melakukan penelitian lebih lanjut mengenai faktor yang menyebabkan terjadinya penunggakan pembayaran yang mengarah kepada piutang tak tertagih.
\end{abstract}

Kata Kunci : Piutang tak tertagih, t-test one sample

\section{PENDAHULUAN}

Penjualan kredit atas barang atau jasa kepada pihak de bitur akan menimbulkan tuntutan (claim) atau tagihan (piutang). Bagi perusahaan yang melakukan kegiatan penjualannya dengan perjanjian dimana pembayaran dilakukan secara bertahap atau diangsur. Maka, piutang yang merupakan salah satu asset perusahaan yang berpengaruh harus dikontrol karena akan mempunyai resiko pada penagihan piutang dan pelunasannya, seperti resiko piutang tidak terbayar tepat waktu atau yang sudah melewati batas tanggal jatuh tempo (overdue). Piutang overdue ini mengakibatkan cashflow terhambat sehingga mengganggu keuangan dan kinerja perusahaan tersebut.

Piutang merupakan salah satu instrument penting dalam pengelolaan perusahaan. Besar kecilnya piutang sangat berpengaruh terhadap kinerja perusahaan. Piutang yang terlalu besar dapat membahayakan kelangsungan hidup perusahaan. Hal ini adanya resiko yang dihadapi perusahaan yaitu adanya kemungkinan kegagalan perusahaan.

Dalam melakukan penagihan, perusahaan juga memiliki kendala yang dihadapi. Keterlambatan pembayaran (jatuh tempo), barang yang telah dibeli konsumen tidak ada atau hilang. Kendala seperti inilah yang menyebabkan kerugian pada piutang tak tertagih. Dengan kata lain manajemen perusahaan juga harus mempertimbangkan resiko dari penjualan kredit yaitu adanya kemungkinan penunggakan pembayaran hingga resiko terjadinya penumpukan piutang. Kurangnya pengelolaan atas piutang mengakibatkan kerugian yang cukup besar. Piutang pada dasarnya merupakan sumber pendapatan perusahaan yang harus dikendalikan dengan sebaik-baiknya, bagi beberapa perusahaan. Prosedur yang wajar dan cara pemahaman yang cukup terhadap piutang adalah 
pentingnya bukan saja untuk keberhasilan perusahaan, tetapi juga untuk memelihara hubungan yang memuaskan dengan para pelanggan..

Menurut Fahmi (2012), piutang merupakan bentuk penjualan yang dilakukan oleh suatu perusahaan dimana pembayaranya tidak dilakukan secara tunai, namun bersifat bertahap. Penjualan piutang artinya lebih jauh perusahaan menerapkan manajemen kredit. Salah satu target dari manajemen kredit adalah tercapainya target penjualan sesuai dengan perencanaan, serta selanjutnya menunggu masuknya dana angsuran ke kas perusahaan.

Peningkatan piutang yang diiringi piutang tak tertagih perlu mendapat perhatian. Untuk itu suatu perusahaan memutuskan melakukan penjualan secara kredit, maka terlebih dahulu memperhitungkan dana yang diinvestasikan dalam piutang, syarat penjualan danpembayaran yang diinginkan kemungkinan terjadi kerugian pada piutang tak tertagih dan biaya yang akan timbul dalam menangani piutang.

Edi (2013) melakukan penelitian tentang piutang tak tertagih pada Bima Finance Palembang. Berdasarkan hasil penelitian, dapat disimpulkan bahwa PT. Bima Finance Palembang memiliki permasalahan pada piutang usaha atau adanya penunggakan piutang, hal ini terjadi karena konsumen melakukan penunggakan pembayaran yang melebihi 30 hari dari tanggal jatuh tempo untuk pembayaran angsuran kredit mobilnya. Kondisi piutang yang tidak tertagih pada perusahaan dari tahun 2009 sampai tahun 2012 mengalami kenaikan yang melebihi ketentuan perusahaan mengenai presentasi piutang yang tak tertagih yaitu lebih dari $3 \%$.

Piutang tak tertagih biasanya pihak perusahaan menetapkan presentase tertentu untuk menggambarkan seberapa besar pengaruhnya terhadap kondisi keuangan perusahaan. Biasanya pengenaan presentasenya ditentukan berdasarkan umur piutang tersebut, dan berdasarkan pengalaman priode yang lalu. Dalam proses mencairkan piutang untuk menjadi kas perusahaan, diperlukannya sistem yang memadai sehingga diharapkan semua piutang dapat ditagih. Jika piutang tidak tertagih pada perusahaan cukup besar, maka hal ini akan mengurangi bentuk piutang yang terealisasi dan akan mengalami kerugian pada perusahaan.

PT. Astra International Tbk, sebagian besar dari aktivitasnya penjualan yang dilakukan secara kredit. Dengan strategi penjualan secara kredit, perusahaan mempunyai harapan dapat meningkatkan pendapatan perusahaan, sehingga perusahaan bisa memperoleh keuntungan. Kurangnya pemahaman dalam menilai kemampuan pelanggan dalam pemberian kredit sehingga berdampak pada penunggakan pembayaran yang melebihi jangka waktu yang telah ditentukan dan kemungkinan beresiko pada kerugian piutang tak tertagih.

Berdasarkan data dari laporan neraca PT. Astra International Tbk, jumlah piutang tak tertagih setiap tahunnya terus meningkat. Pada tahun 2012 jumlah piutang tak tertagih sebesar Rp. 4.339.000.000, sedangkan tahun 2013 naik sebesar Rp. 6.221.000.000, dan tahun 2014 mengalami kenaikan lagi sebesar Rp. 8.063.000.000, tahun 2015 piutang tak tertagih lebih rendah dari tahun 2014 
yaitu sebesar Rp. 6.923.000.000, dan tahun 2016 piutang tak tertagih sebesar Rp. 6.145.000.0000 (www.astra.co.id).

Peningkatan dan penurunan piutang pada PT. Astra International Tbk disebabkan sering terjadinya pembayaran yang melewati jangka waktu yang telah ditetapkan oleh perusahan, sehingga terjadi penumpukan piutang dan beresiko pada kerugian piutang tak tertagih, dan menjadi ancaman bagi perusahaan yang mengakibatkan mengganggu kinerja perusahaan. Masalah penagihan piutang usaha perlu mendapat perhatian, agar resiko yang akan timbul dapat dihindarkan sekecil mungkin. Manajemen harus aktif mengelola piutang agar piutang yang telah jatuh tempo, agar tidak sampai menghambat kegiatan opersional perusahaan.

Berdasarkan uraian permasalah diatas, maka dapat dirumuskan masalah pada penelitian ini adalah seberapa besar piutang tak tertagih pada PT Astra International Tbk.

\section{TINJAUAN PUSTAKA}

\section{Piutang}

Piutang menunjukkan adanya klaim perusahaan kepada pihak (perusahaan) lain akibat kejadian diwaktu sebelumnya dalam bentuk uang, barang, jasa atau dalam bentuk aktiva non kas lainnya yang harus dilakukan penagih (collect) pada tanggal jatuh temponya (Syakur, 2015). Piutang usaha dapat berupa tagihan yang timbul karena penjualan barang dagangan, jasa atau penjualan aktiva lainnya yang dilakukan secara kredit dan transaksi-transaksi lain yang dapat menimbulkan klaim kepada pihak lain.

\section{Jenis-Jenis Piutang}

1. Piutang dagang (Account Receivable)

Berasal dari tranksaksi penjualan barang atau jasa yang dilakukan secara kredit.

2. Piutang Wesel (Notes Receivable)

Piutang wesel merupakan tagihan perusahaan yang didukung dengan instrumen formal sebagai bukti tagihan disebut surat wesel. Piutang wesel biasanya memiliki jangka waktu 60-90 hari atau bahkan lebih panjang, dengan kewajiban bagi si debitur untuk membayar bunga (Jusup, 2011: 72)

3. Piutang lain-lain (Non Account And Receivable).

Piutang lain-lain Mencakup semua tagihan yang bukan piutang usaha. Termasuk dalam jenis piutang ini adalah piutang yang timbul dari pemberi pinjaman kepada pihak lain, pinjaman kepada para karyawan, uang muka gaji kepada karyawan, dan uang muka pajak (pajak yang ditangguhkan).

\section{Faktor-faktor yang Mempengaruhi Jumlah Piutang}

Faktor-faktor yang mempengaruhi jumlah piutang adalah sebagai berikut (Bambang, 2005):

1. Volume penjualan kredit 
Makin besar penjualan kredit dari keseluruhan penjualan akan memperbesar jumlah piutang dan sebaliknya makin kecil jumlah penjualan kredit dari keseluruhan piutang akan memperkecil jumlah piutang.

2. Syarat pembayaran penjualan kredit

Semakin panjang batas waktu pembayaran kredit berarti semakin besar jumlah piutangnya dan sebaliknya semakin pendek batas waktu pembayaran kredit berarti semakin kecil besarnya jumlah piutang.

3. Ketentuan dalam pembatasan kredit

Apabila batas maksimal volume penjualan kredit ditetapkan dalam jumlah yang relatif beaar maka besarnya piutang juga semakin besar.

4. Kebijakan dalam pengumpulan piutang

Perusahaan dapat menjalankan kebijakan dalam pengumpulan piutang dalam dua cara yaitu aktif dan pasif. Perusahaan yang menjalankan kebijaksanaan secara aktif dalam pengumpulan piutang akan mempunyai pengeluaran uang yang lebih besar dibandingkan perusahaan lain yang menggunakan kebijaksanaannya secara pasif.

5. Kebiasaan membayar dalam pelanggan

Semua piutangnya diperkirakan akan terealisasikan menjadi kas dalam setahun dineraca di sajikan pada bagian aktiva lancar.

\section{Piutang Tak Tertagih}

Menurut Kieso, et al (2012) menyatakan bahwa piutang usaha tak tertagih adalah kerugian pendapatan yang memerlukan, melalui ayat jurnal pencatatan yang tepat dalam akun, penurunan aktiva piutang usaha serta penurunan yang berkaitan dengan laba dan ekuitas pemegang saham. Kerugian pendapatan dan penurunan laba diakui dengan mencatat beban piutang ragu-ragu (beban piutang tak tertagih). Terdapat beberapa metode penghapusan piutang yang dapat digunakan yakni sebagai berikut.

1. Metode penghapusan langsung (Direct Write Off Method)

Dalam metode ini, kerugian piutang akan dicatat pada saat perusahaan mendapat kepastian bahwa suatu piutang kepada debitur tertentu tidak akan dapat ditagih lagi (jusup, 2011 :76). Dalam penghapusan piutang saldo kepada pelanggan tertentu dikeluarkan dari catatan perusahaan. Dengan penghapusan langsung nama dan saldo piutang pelanggan tidak akan muncul dalam rincian piutang. Piutang dagang harus dilaporkan sebesar nilai realisasi bersihnya, yaitu piutang usaha dikurangi piutang yang tak tertagih.

2. Metode Pencadangan (Allowance Method)

Sepanjang periode dimana penjualan kredit terjadi, estimasi mengenai besarnya piutang usaha yang tidak dapat ditagih dibuat. Karena perusahaan belum dapat mengetahui mana dari pelanggannya yang tidak bisa membayar maka perusahaan tidak akan mengkredit (menghapus) 
piutang usahanya secara langsung. Satu hal yang perusahaan dapat prediksi adalah bahwa berdasarkan pengalaman masa lampau selalu ada pelanggannya yang tidak bisa membayar. Dengan menggunakan metode pencadangan, besarnya estimasi atas beban piutang yang tak tertagih akan diakui (dicatat) dalam periode yang sama sebagaimana penjualan kredit dicatat, tanpa harus menunggu terjadinya actual loss yang mungkin baru terjadi setelah periode penjulan berlangsung. (Hery, 2012).

\section{METODE PENELITIAN}

Metode penelitian yang digunakan dalam penelitian ini adalah metode penelitian deskriptif, dimana penelitian ini dilakukan untuk mengetahui nilai variabel mandiri (Sugiono, 2012 :13). Variabel mandiri pada penelitian ini adalah piutsng tak tertagih. Jenis data yang dibutuhkan pada penelitian ini adalah data kuantitatif berupa Laporan Neraca PT. Astra International Tbk selam 5 tahun mulai dari tahun 2012 sampai dengan tahun 2016. Data laporana keuangan di ambil dari website PT Astra Internasional Tbk dan www.idx.com

Teknik sampling yang digunakan adalah Nonprobability Sampling yaitu Sampling Purposive adalah teknik penentuan sampel dengan alasan/kriteria tertentu (Sugiyono, 2009). Sampel penelitian dalam penelitian ini yaitu selama 5 (lima) tahun, mulai tahun 2012 sampai dengan tahun 2016.

\section{Teknik Analisis Data}

1. Analisis Rasio Tunggakan (Piutang Tak Tertagih)

Menurut Keown (2008), Rasio ini digunakan untuk mengetahui seberapa besar jumlah piutang yang telah jatuh tempo dan belum tertagih dari total piutang yang dilakukan perhitungan sehingga dapat dirumuskan sebagai berikut:

$$
\text { Rasio Tunggakan }=\frac{\text { Jumlah Piutang Tak Tertagih }}{\text { Total Piutang }} \times 100 \%
$$

Tinggi rendahnya piutang tidak tertagih mempunyai efek langsung terhadap besar kecilnya dana yang dinvestasikan dalam piutang, makin tinggi piutang yang tertunggak berarti makin besar resiko piutang yang tidak tertagih.

Tabel 1. Standar Pengukuran Piutang tak tertagih

\begin{tabular}{ccc}
\hline Rasio & Persentase & Kriteria \\
\hline \multirow{2}{*}{ Rasio Tunggakan } & $>3$ & Besar \\
\cline { 2 - 3 } & $\leq 3$ & Kecil
\end{tabular}

Sumber: Erdi Kurniawan (2013)

2. Uji T-Test One Sample.

Untuk pengujian secara statistik dengan menggunakan T-Test One sample, teknik analisis ini digunakan karena penelitian ini merupakan penelitian deskriptif yakni dugaan terhadap nilai satu variabel secara mandiri antara data sampel dan data populasi. 
Rumus yang digunakan dalam menerapkan uji t ini adalah sebagai berikut:

$$
t=\frac{\bar{x}-\mu_{0}}{\mathrm{~s} / \sqrt{n}}
$$

Keterangan:

$\bar{x}=$ Rata-rata hasil pengambilan data

$\mu_{0}=$ Nilai rata-rata ideal.

$s \quad=$ Standar deviasi sampel

$\mathrm{n}$ = Jumlah sampel

\section{HASIL DAN PEMBAHASAN}

Berikut hasil perhitungan rasio tunggakan (piutang tak tertagih) disajikan dalam bentuk tabel dari tahun 2012 sampai 2016.

Tabel 2. Rasio Tunggakan (Piutang Tak Tertagih) PT. Astra Internasional Tbk

Tahun 2012 - 2016

\begin{tabular}{cccccc}
\hline No & Priode & $\begin{array}{c}\text { Piutang tak } \\
\text { tertagih } \\
\text { (Tertunggak) }\end{array}$ & Total Piutang & $\begin{array}{c}\text { Presentasi } \\
\text { piutang tak } \\
\text { tertagih }(\%)\end{array}$ & Keterangan \\
\hline 1 & 2012 & 4.339 .000 .000 & 15.443 .000 .000 & 2,80 & Kecil \\
\hline 2 & 2013 & 6.221 .000 .000 & 19.843 .000 .000 & 3,13 & Besar \\
\hline 3 & 2014 & 8.063 .000 .000 & 21.332 .000 .000 & 3,77 & Besar \\
\hline 4 & 2015 & 6.923 .000 .000 & 17.776 .000 .000 & 3,89 & Besar \\
\hline 5 & 2016 & 6.147 .000 .000 & 18.946 .000 .000 & 3,24 & Besar \\
\hline & & Rata - Rata & & 3,36 & Besar \\
\hline
\end{tabular}

Sumber: data skunder yang diolah, 2018

Piutang tak tertagih pada PT Astra International Tbk, selama 5 tahun mengalami fluktuatif, dimana pada tahun 2012 total penunggakan (piutang tak tertagih) sebesar Rp 4,339,000,000 dari total piutang sebesar Rp 15.443.000.000 diperkirakan penunggakan piutang mencapai 2,80\%, pada tahun 2013 naik dari tahun sebelumnya piutang tak terrtagih yaitu sebesar Rp 6.221.000.000 dari total piutang sebesar Rp 19.843.000.000 dengan penunggakan piutang sebesar 3,13\%, kemudian tahun 2014 total piutang tak tertagih meningkat sebesar Rp 8.063.000.000 dari total piutang sebesar $\mathrm{Rp}$ 21.332.000.000 dan penunggakan piutang sebesar 3,77\%, ditahun 2015 piutang tak tertagih mengalami peningkatan lagi sebesar Rp 6.923.000.000 dan penunggakan piutang mencapai 3,89\% dan tahun 2016 mengalami menurun piutang tak tertagih sebesar Rp6.147.000.000 dari total piutang sebesar Rp 18.946.000.000 dan penunggakan piutang (piutang tak tertagih) sebesar 3,24\%. Di mana terjadinya penunggakan atau piutang tak tertagih, diakibatkan adanya pihak debitur mengalami kebangkrutan. 


\section{Pembahasan (Interpretasi Data)}

\section{Menghitung Nilai Rata-rata (x)}

Untuk menghitung nilai rata-rata dari jumlah keseluruha selisih dari tahun 2012-2016 dibagi dengan jumlah tahun pengambilan data.

$$
\begin{aligned}
& x=\frac{\sum X}{n} \\
& x=\frac{16,83}{5} \\
& x=3.36
\end{aligned}
$$

2. Standar Devisiasi (s)

$$
\begin{aligned}
S & =\sqrt{\frac{\left.\sum X 1-\bar{X}\right)}{n-1}} \\
S & =\sqrt{\frac{0,8181}{5-1}} \\
S & =\sqrt{\frac{0,8181}{4}} \\
S & =\sqrt{0,204} \\
& =0,45
\end{aligned}
$$

\section{Menghitung T-test One Sampel (Uji T) sebagai berikut:}

Selanjutnya memasukan angka-angka tersebut kedalam rumus t-test one sampel untuk variabel piutang tak tertagih $(\mathrm{X})$ :

$$
\begin{aligned}
& \mathrm{t}_{\text {hitung }}=\frac{\bar{X}-\mu 0}{\frac{s}{\sqrt{n}}} \\
& \mathrm{t}_{\text {hitung }}=\frac{3.36-3}{\frac{0,45544}{\sqrt{5}}} \\
& \mathrm{t}_{\text {hitung }}=\frac{0,36}{\frac{0,45544}{2,23606}} \\
& \mathrm{t}_{\text {hitung }}=\frac{0,36}{0,2036} \\
& \mathrm{t}_{\text {hitung }}=1,79
\end{aligned}
$$

\section{Pengujian Hipotesis}

H0 : $\mu>3 \%$ : Diduga Piutang Tak Tertagih pada PT Astra International Tbk lebih dari 3\% dari yang diharapkan.

Ha : $\mu \leq 3 \%$ : Diduga Piutang Tak Tertagih pada PT. Astra International Tbk, kurang dari sama dengan 3\% dari yang diharapkan. 


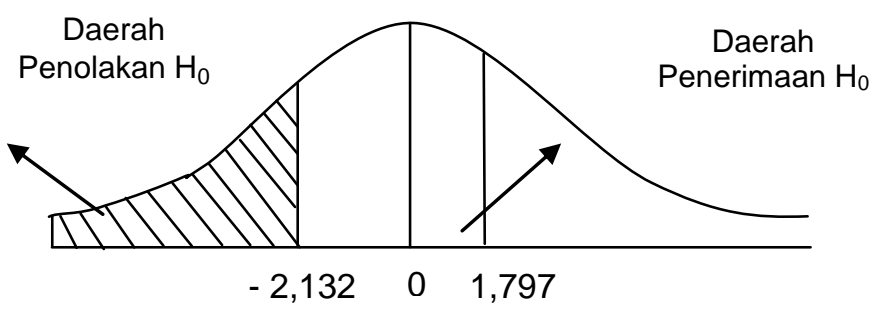

Gambar 1. Kurva Uii Hipotesis Pihak Kiri

Berdasarkan hasil diatas maka nilai t hitung untuk variabel piutang tak tertagih adalah sebesar 1,797 kemudian nilai $t$ tabel tersebut akan dibandingkan dengan $t$ hitung dengan derajat kebebasan $(\mathrm{dk})=\mathrm{n}-\mathrm{k}=5-1=4$, dan taraf kesalahan $5 \%(0,05)$ untuk uji satu fihak (one tail test) pihak kiri, didapat nilai $\mathrm{t}_{\text {tabel }}$ (pada lampiran tabel daftar distribusi t) adalah sebesar -2,132.

Jika dibandingan antara nilai $t_{\text {tabel }}$, dengan $t_{\text {hitung }}$, maka $t_{\text {tabel }}$ lebih kecil dari $t_{\text {hitung }}(-2,132<1,797)$, sehingga jatuh pada daerah penerimaan $\mathrm{H}_{0}$ yang piutang tak tertagih pada PT Astra International Tbk lebih dari 3\% dari yang diharapkan.

\section{KESIMPULAN DAN SARAN}

Berdasarkan hasil penelitian dan pembahasan yang telah diuraikan sebelumnya maka dapat ditarik kesimpulan sebagai berikut bahwa piutang tak tertagih PT Astra Interanasional Tbk rata - rata selama 5 tahun terakhir sebesar 3,36 \% yang berarti masuk dalam kategori besar. Dari hasil pengujian hipotesis diperoleh bahwa piutang tak tertagih pada PT Astra International Tbk lebih dari 3\% dari yang diharapkan.

Saran untuk kesempurnaan penelitian selanjutnya adalah diharapkan menambah tahun penelitian dan menggunakan data terbaru dan dapat melakukan penelitian lebih lanjut mengenai faktor yang menyebabkan terjadinya penunggakan pembayaran yang mengarah kepada piutang tak tertagih.

\section{REFERENSI}

Al Haryono Jusuf. 2011. Dasar-dasar Akuntansi. Cetakan Ketujuh. Yogyakarta: Sekolah Tinggi Ekonomi Yayasan Keluarga Pahlawan Negara.

Arthur J. Keown. 2008. Manajemen Keuangan. Edisi 10. Jakarta: PT Macanan Jaya Cemerlang.

Bambang Riyanto. 2005. Dasar-Dasar Pembelanjaan Perusahaan. Edisi Keempat. Cetakan Ketujuh. Yogyakarta: YBPF UGM.

Dwi Martani, dkk. 2012. Akuntansi Keuangan Manengah Berbasis PSAK. Jakarta: Salemba Empat.

Edi Kurniawan Syahputra. 2013. Analisis Piutang Tak Tertagih pada PT Bima Finance Palembang. Jurnal Akuntansi S1. STIE MDP.

Fahmi Irham. 2012. Pengantar Manajemen Keuangan, Teori Soal dan Jawab. Bandung: Alfabeta.

Hery Purwono. 2012. Akutansi Keuangan Menengah I. Edisi . Ccetakan pertama. Jakarta: Penerbit PT. Bumi Aksar.

Kieso Donald. E, Weygendt, Jerry. J. 2012. Intermediate Accounting. Jilid 1. Edisi Keduabelas. Jakarta: Erlangga.

Sugiyono. 2012. Memahami Penelitian Kuantitatif. Bandung: Alfabeta.

Syakur, Syafi'i Ahmad. 2015. Intermediate Accounting. Jakarta: AV Publisher. 